and social studies undertook further education or training and 38 per cent entered employment; $55 \cdot 7$ per cent of the women undertook further education or training compared with 39.4 per cent of the men. However, while 13.0 per cent of men undertook research or further academic study, only 7.0 per cent of the women did so; on the other hand, 34.5 per cent of women undertook teacher training compared with 17.9 per cent of the men.

For pure and applied science, taking men and women together, 36.9 per cent undertook further education or training and 50.9 per cent entered employment; for the men, the corresponding figures are 50.3 per cent and 39.3 per cent in pure science and 17.5 per cent and $66 \cdot 1$ per cent in applied scionce, and for women in pure and applied science, 41.6 per cent and $50 \cdot 2$ per cent. For graduates in both arts and social studies and in pure and applied science, only $2 \cdot 2$ per cent entered employment overseas, but for mon this figure was 2.8 per cent for applied science and 1.9 per cent for puro science. Of science graduates who entered employment within the United Kingdom, 9.3 per cent of the men entered the public service (other than education), 19.7 per cent education (in schools, colleges and universities without postgraduate training first) and $66 \cdot 3$ per cent industry and commerce; for graduates in applied science the corresponding figures are $10.4,2.8$ and 84.9 per cent, respectively; and for women graduates in pure and applied science, 22.9, 43.3 and 29.3 por cent, respoctively. For graduates in arts and social studies, 13.9 per cent of the men entered the public service, 19.9 per cent education, and 46.5 per cent industry and commoree; for women the corresponding figures are $21 \cdot 8,48 \cdot 7$ and $17 \cdot 2$ per cent, respectively.

The report shows that of every 100 men graduating in puro scieneo, 31 undertake research or further academic study and 14 undertake teacher training; in applied science these figures are 16 and 1, respectively, and for womon in pure and applied science 13 and 25 , respectively. Over the past five years, the proportion of graduates in pure and applied science undertaking teacher training has risen slightly from 9 to 11 per cent, and of those undertaking research or further academic study from 22 to 23 per cent, but the proportion gaining employment at home in education or gaining employment overseas has remained unchanged at 7 per cent and 2 per cent, respectively.

\title{
SULPHATE EXPANSION IN CONCRETE: A NEW HYPOTHESIS
}

\begin{abstract}
$\mathrm{T}$
HE phenomenon of sulphate expansion in cement paste or concrete is a well-known hazard to be reckoned with in building and highway construction by civil engineers and others concerned. For example, in highly gypsiferous clays, such as obtain at certain horizons and places in the London Clay, the use of ordinary Portland cement concrete is avoided in favour of sulphateresisting or aluminous cements. The causes of sulphate attack in concrete have received international attention over the years, but even to-day the precise mechanism of the reaction is still an open question.

Sulphate expansion means an increase in volume of cement paste or concrete occurring as a result of chemical reaction between the hydration products of cement and sulphate-bearing solutions with which it may come in contact. T. Thorvaldson has stated (1954): "While the formation of crystals of sulpho-aluminate and gypsum in Portland cement mortar during disintegration in sulphate solutions is well established, many observations throw doubt on the assumption that physical forces of crystallization are the primary cause of expansion and loss in strength". Previous theories have assumed that the chief cause of expansion is the formation of ettringite (3CaO. $\mathrm{Al}_{2} \mathrm{O}_{3} \cdot 3 \mathrm{CaSO}_{4} \cdot 31 \mathrm{H}_{2} \mathrm{O}$ ) (Larsen), from aluminabearing compounds present in cements.
\end{abstract}

S. Chatterji and J. W. Jeffery have put forward a new theory which suggests that sulphate expansion is caused by solid-state conversion of calcium aluminate hydrate to calcium aluminate monosulphate and "that this expansion may or may not be accommodated depending on the concentration of lime in the liquid phase" (Magazine of Concrete Research, 15, No. 44; July 1963).

S. Chatterji and A. Grudemo have investigated paste hydration of calcium aluminate gypsum mixtures with and without calcium hydroxide (paper in course of publication). "The pastes, of water/cement ratio $0 \cdot 6$, were contained in brittle plastic vials. In the case of the pastes containing $\mathrm{Ca}(\mathrm{OH})_{2}$, the vials which remained unused after 14 days had cracked by expansion before 3 months, while the three without $\mathrm{Ca}(\mathrm{OH})_{2}$ remained intact. The course of the reaction was followed by X-ray diffraction and electron-optical techniques. It was found that the initial sulphate-bearing compound was ettringite, but the final one was calcium aluminate monosulphate $\left(\mathrm{C}_{3} \mathrm{~A}\right.$. CaSO $\left.\mathrm{SO}_{4} \cdot x \mathrm{H}_{2} \mathrm{O}\right)$ in both cases; the change from ettringite to monosulphate occurred between 14 days and 3 months, the period during which the vials cracked" (see p. 463 of this issue).

The basis of this hypothesis is briefly explained in Chatterji and Jeffery's paper, but, as they rightly point out, the theory on which their explanations rest is far from being established. If it is confirmed by further work, then the next stage is to establish the mechanism of disruption. The hope is expressed that by putting forward this hypothesis now, further research on this subject will be stimulated.

H. B. MuLNER

\section{INTER-INDUSTRIAL OCEANOGRAPHIC RESEARCH IN THE UNITED STATES}

HOUGH no exact figures are availablo, it is reasonably
certain that since the war, and probably for some years
before it, the United States has spent more on oceano-
graphic research than the rest of the Western world put
together. The Federal Government alone is spending 124
million dollars per annum at the present time, and
plans to treble this over the next ten years. Much of this
money is spent on buying or developing equipment, and
a number of small firms have sprung up in the past decade
to satisfy this requirement. However, the sums involved
are now sufficient to interest big business. One Californian oceanographer who was visiting Great Britain last year pointed out that his firm had set up an Oceanographic Systems Group with an initial budget of I million dollars, and had told the Group leader that when he had spent this he should ask for more. At the time of the first conference, commercial firms in California alone employed 32 professionally trained oceanographers (mostly physical oceanographers), quite apart from the supporting staff of engineers. For comparison, the whole of Western Europe can muster about 130 physical oceanographers in all types of employment. 
Most of this expansion has occurred in the sphere of physical oceanography. The incentive is partly military, partly prestige (the U.S.S.R. is also putting tremendous effort into this branch of science), and partly the feeling that this is the world's last major frontier, and that rich rewards will eventually follow on its opening-up. However, a rapid increase in expenditure in this way raises the problem of making sure that the effort is properly directed, and that the minimum of duplication takes place. To this end, the Government agencies have held briefing conferonces for industry, and industry itself has got together in these 'Interindustrial Symposia'* to co-ordinate their efforts and to encourage ocoanographic research generally.

Three of the four papers presented at the first symposium deal with the Co-operative Observation Weeks. This is a programme to study the marine layer of California, which is the layer of the atmosphere between the ocean and the temperature inversion at about $3,000 \mathrm{ft}$. A large number of both public and commercial organizations participated, and the investigations included the surface layer of the ocean. The papers give the background of the project, present a general discussion of the problems of air-sea interaction and discuss the temperature structure of the surface layers of the sea in the Santa Barbara Channel. The fourth paper describes the initial development of an airborne optical method for determining sea

- Lockheed Aircraft Corporation. Proceedings of the First Interindustrial Oceanographic Symposium, Burbank, California, June 14, 1962. Pp. 27. Proceedings of the Second Interindustrial Oceanographic Symposium, Santa Barbara, Calfornia, December heed Aircraft Corporation.) surface slopes, knowledge of which is important, for example, in connexion with radar and underwater acoustics.

The emphasis at the second symposium was rather different, only one of the seven papers dealing with the programme of the Co-operative Observation Weeks. Three of the papers are concerned with the development of unattended buoys for collecting oceanographic information. Some oceanographic problems, such as studies of the movement of deep water and the collection of synoptic wave and temperature data, require data collection over a long period of time at a number of points. The only practicable way to do this is to use anchored unattended buoys which either collect and record the data, or transmit it over a radio telemetering system to a ship or shore station. Such buoys are being developed in several places (including Norway under NATO auspices). Two such systems are described, and one paper deals with the problem of telemetering information by radio from a large number of such buoys over the limited radio channels available. The other three papers deal with numerical wind-wave forecasting, acoustic scattering measurements as indicators of water inhomogeneities and the Hughes Research Program in Marine Geophysics and Oceano. graphy.

One is left with the impression that firms in the United States do a surprising amount of oceanographic research, but that much of this is supported by public funds and is directly or indirectly aimed at defence applications.

M. J. TUOKER

\section{GELATINE AND GLUE RESEARCH}

$\mathrm{T}$ HE twenty-fifth meeting of the research panel of the Gelatine and Glue Research Association* was held on May 29 at the Strand Palace Hotel, London, W.C.2. The chairman of the Association, Mr. S. G. Hudson (Richard Hodgson and Sons, Beverley), presided and welcomed Mr. D. N. Carvalho and Mr. E. E. Werle (Darling and Co., Chicago) and Mr. T. V. Simpson (Canada Packers, Ltd., Toronto) to their first meeting as members of the Association.

The two morning papers were "Effect of Ionizing Radiation on Collagen", by Dr. A. J. Bailey (Low Temperature Research Station, Cambridge), and "Unusual Links and Cross-links in Collagen", by Mr. J. J. Harding (Medical Research Council grant, the Gelatine and Glue Research Association). The two papers were complementary, since Dr. Bailey discussed the formation of new cross-links in the unusual type of collagen existing in rat tail tendon, while Mr. Harding discussed recent work on the structure of cross-links already existing in mature collagen. In the presence of isotonic saline, irradiation causes a progressive lowering of shrinkage temperature (for example, by $14^{\circ} \mathrm{C}$ after $5 \mathrm{Mrads}$ ) which is accompanied by increased shortening of fibres during thermal shrinkage, by decreased solubility and by decreased tensile strength. However, if the influence of hydrogen bonds in the tendons is eliminated by thermal contraction, then the tensile strength of irradiated samples is higher than that of thermally contracted control samples. Dr. Bailey concluded that irradiation disrupts some of the helical structure and produces new thermally stable bonds. Dr. J. Bowes and Mr. C. W. Cater (British Leather Manufacturers' Research Association) have made stress-strain measurements of irradiated, thermally shrunk fibres, estimating that the number of cross-links per tropocollagen unit of $M=360,000$ rises from 1 to 36 after 46 Mrads.

* Until April 1963 this was the British Gelatine and Glue Research Association. The change of name was made in recognition of the growing Association. The change of the Association.
The most probable cross-linking site is thought to be the side-chains of the polar amino-acids, and chemical investigations are in progress to explore the structure formed which may arise from a radical reaction resulting in carbon-carbon bonding. It is believed that in mature collagens there are unusual links which have not yet been found to any extent in other proteins. A voluminous and expanding literature exists on the occurrence of ester links, $\gamma$-glutamyl links, $\varepsilon$-amino lysine links and links through bound hexose residues. Mr. Harding reviewed the present position, which has a considerable bearing on his own attempts to compare human collagens from different organs. The discussion on these two papers, which was opened by Dr. Bowes, served to emphasize the difficulties of interpreting experimental results on the nature of natural and induced cross-links in collagen. It is, however, clear that considerable progress is at last being made.

In the afternoon, two papers of practical interest to the glue and gelatine industry were read. Mr. B. E. Purkiss (British Drug Houses, Ltd.) and Mr. J. R. Marsh (Cork Manufacturing Co., Ltd.) contributed "Fungicides for Composition Cork". They have recently solved the problem of finding a satisfactory fungicide for this material. The fungicide is the magnesium derivative of dehydroacetic acid and has been given the trade name 'Lastil'. Finally, Mr. F. W. Wainewright (The Gelatine and Glue Research Association) described and demonstrated "The Redesigned Bloom Gelometer', which incorporates the improvements made by the Association in collaboration with Messrs. Griffin and George, Ltd., over a number of years. The redesigned instrument is capable of giving more accurate and reproducible results and is now available commercially. Mr. Wainewright has revised the Association's Research Report (Series B.7) on "The Standardization of Bloom Jelly Strength Testing", by D. Fysh and A. G. Ward, in order to include operating instructions for the new instrument. D. A. Surton 